\title{
Bronzový predmet so zoomorfnými protómami zo Slovenského krasu
}

\section{A bronze object with zoomorphic protomes from the Slovak Karst}

\author{
Elena Miroššayová
}

\begin{abstract}
Abstrakt
Z územia Slovenského krasu poznáme skupinu nálezov z neskorej doby bronzovej a doby halštatskej s paralelami vo vzdialených kultúrnych prostrediach. Článok sa zaoberá vyhodnotením ojedinelého nálezu predmetu so zvieracími protómami z hradiska Havrania skala v obci Bôrka, okr. Rožňava, ktoré bolo súčast'ou sídliskovej aglomerácie kyjatickej kultúry v blízkosti cesty Zádielskou tiesňavou $\checkmark$ Slovenskom krase. Predmet tvarom pripomína "slnečnú bárku". Rovnako neobvyklá je aplikácia odlišných motívov - býčej hlavy a vtáka. V kontexte s bronzovými nálezmi cudzej proveniencie zo Zádielu a z jaskyne Kamenná tvár v Háji je nález z Bôrky datovaný do staršej doby halštatskej.
\end{abstract}

\section{Kl'účové slová}

Slovensko, Slovenský kras, bronzový predmet, staršia doba halštatská

\begin{abstract}
From the territory of the Slovak karst we know the group of bronze finds from the Late Bronze and Hallstatt Period with parallels in distant cultural environments. The article focuses on evaluation of the unique find of an object with zoomorphic protomes from the Vrania skala hillfort in Bôrka, Rožňava District, which was part of a settlement agglomeration of the Kyjatice Culture near Zádielská tiesňava gorge in the Slovak Karst. The shape of the object imitates a "sun boat". Application of different symbols - a bull's head and a bird - also is unusual. In the context of a group of foreign bronze finds from Zádiel and from the Kamenná tvár Cave in Háj, the find from Bôrka is dated to the Early Hallstatt period.
\end{abstract}

\section{Keywords}

Slovakia, Slovak Karst, bronze object, Early Hallstatt period

Príspevok je súčastou riešenia Grantového projektu VEGA 2/0030/15 a 2/0032/15.

The paper was elaborated as a part of the grant project VEGA 2/0030/15 and 2/0032/15. 


\section{Geografická lokalizácia nálezu}

Podla dostupných údajov sa predmet našiel na polohe Havrania skala², v katastri obce Bôrka, okr. Rožňava v severnej časti geografického celku Slovenský kras (obr. 1: 1). Bližšie informácie o nálezovom kontexte chýbajú (Soják 2007, 70, obr. 102).

\section{Popis}

Polooblúkovitý tvar odlievaného bronzového predmetu vychádza z formy „slnečnej bárky“. Tvarovanie koncov je rozdielne. Na jednom boli po odliatí základu pripevnené rohy z tyčinky kruhového prierezu, druhý prehnutý má roztepaný vejárovitý chochol. V centrálnej, rozšírenej časti sú dva otvory na upevnenie k podložke, prípadne na zavesenie (obr. 2: 1). Predmet pokrýva sivozelená patina. Rozmery: šírka $81 \mathrm{~mm}$, hmotnost 19,02 g.

\section{Vyhodnotenie}

Na náleze z Bôrky je pozoruhodná kombinácia hlavy býka a vtáka. Spojenie dvoch pôvodne samostatných symbolov sa pokladá za ohlas nových ideí prenikajúcich do duchovného sveta populácií neskorých popolnicových polí a staršej doby halštatskej. Nová symbolika prichádza vo viacerých vlnách na rozličných miestach okruhu východných popolnicových polí, v severskom okruhu a v Taliansku. Zdrojom ich šírenia bol severozápadný Balkán a východoalpské prostredie (Kossack 1954, 53).

V severopotiskom prostredí gávskej kultúry sú dva rôzne symboly aplikované na bronzovej zoomorfnej nádobe z Čičaroviec, okr. Michalovce na Východoslovenskej nížine (obr. 2: 2). Telo vtáka, frekventovaného symbolu popolnicových polí, doplňujú býčie rohy na hlave. Nádoba vyrobená pre kultové účely sa chronologicky radí do časového horizontu neskorých popolnicových polí (Novotná 1991, 66n., Taf. 12: 62). Modelácia vtáčej hlavy s vejárovitým chocholom na predmete z Bôrky (obr. 2: 1) sa odlišuje od plynulých línií štylizovaných hláv vodných vtákov. Odsadenie hlavy od zobáka majú napríklad naznačené vtáčie protómy (obr. 2: 5) vytepané na bronzových vedrách typu Hajdúböszörmény vyrábaných v stupni HB1 v produkčných centrách gávskej kultúry $\mathrm{v}$ oblasti Nyírség na severe Vel'kej mad’arskej nížiny (Patay 1990, 43, Taf. 30-34). Gravírované a tepané paralely k vyobrazeniu vtáka s chocholom (obr. 2: 3, 4, 6) sa nachádzajú na časovo mladších bronzových výrobkoch $\mathrm{z}$ východoalpských produkčných centier východohalštatského okruhu (Kossack 1954, 69, Taf. 8: 3, 13, 14; Podborský 1993, 348, 229: 32). Spôsob vytvorenia chochola zásekmi na predmete $z$ Bôrky je podobné hrive koňa na symbolickej sekerke z pohrebiska v Hallstatte (hrob 504 - Krieger und Salzherren 1970, Taf. 18). S prenikaním východných jazdeckých skupín do Karpatskej kotliny sa v živote spoločenstiev kultúr neskorých popolnicových polí a staršej doby halštatskej posilňuje hospodárska a spoločenská úloha koní (podrobnejšie Kmetová 2014, 280n.; Kmetová - Stegmann-Rajtár 2015). Kombinácia symbolu koňa a býka je neobvyklá a úvaha o možnosti, či bola použitá na náleze z Bôrky, zostáva iba v rovine hypotézy.

Ďalšie interpretačné možnosti bronzového predmetu z Bôrky sú limitované chýbajúcim nálezovým kontextom. Hoci spoločné použitie symbolov býka a vtáka sa objavuje v neskorej dobe bronzovej, predmet z Bôrky datujem najskôr do staršej doby halštatskej. Vychádzam z podoby vtáčieho protómu a symbolu býka, ktorého frekvencia výskytu v severokarpatskom kultúrnom prostredí v dobe halštatskej narastá. Rôzne modifikácie hlavy býka sú aplikované na pleciach nádob kalenderberskej kultúry (Pichlerová 1969, 157n., Tab. VI; XXVIII: 1; XXIX). 


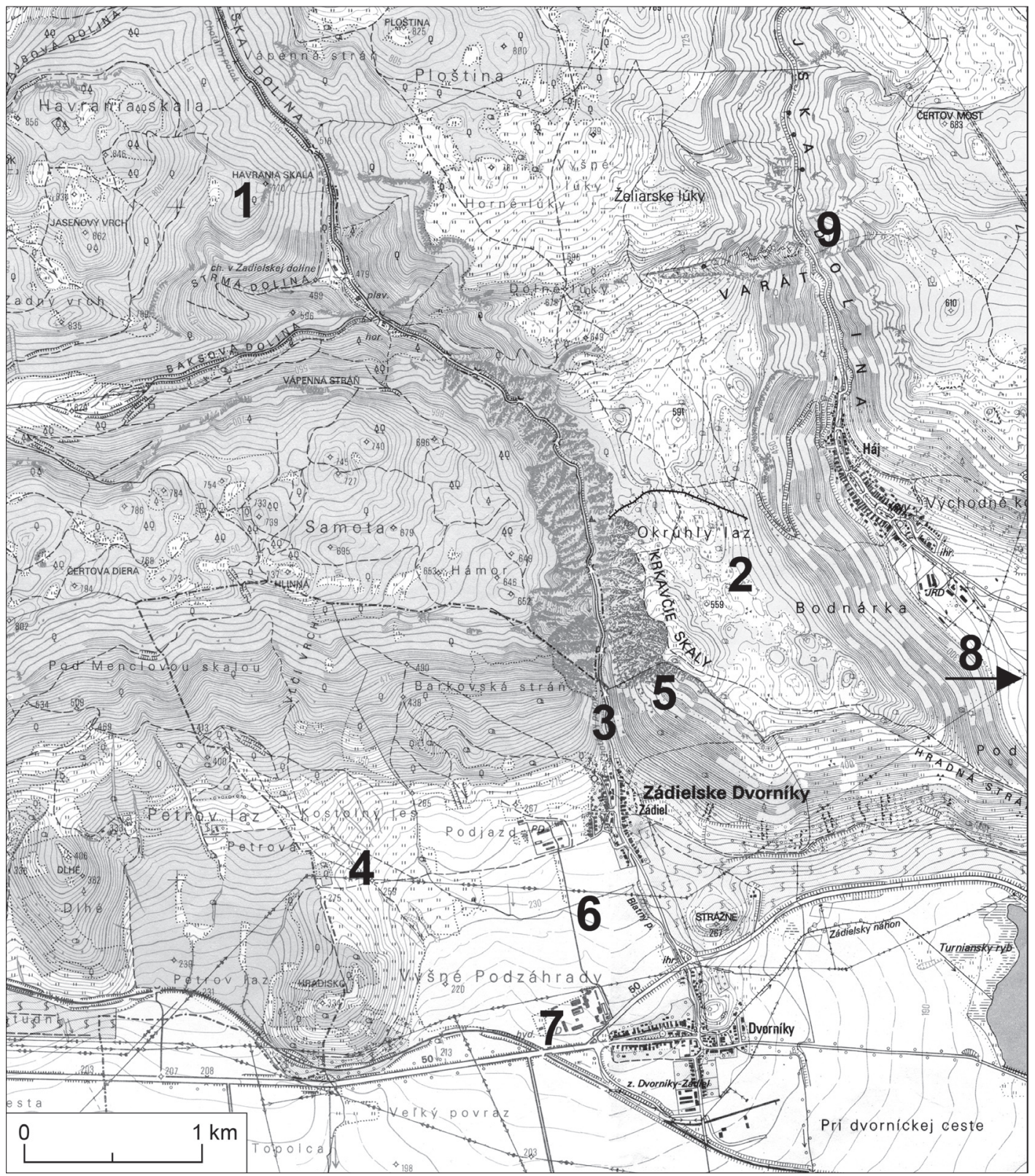

Obr. 1. Sídlisková aglomerácia v okolí Zádielskej tiesňavy (neskorá doba bronzová, doba halštatská).

1 - hradisko Havrania skala; 2 - Zádielske hradisko; 3, 6- osady; 4 - miesto nálezu náramku; 5 - Kostrová jaskyňa; 7 - pohrebisko (doba bronzová mladá, neskorá); 8 - jaskyňa Kamenná tvár; 9 - Slaninová jaskyňa.

Fig. 1. Settlement agglomeration near the Zádielska tiesňava canyon (Late Bronze Age, Hallstatt period).

1 - the Havrania skala hillfort; 2 - Zádiel hillfort; 3,6 - settlements; 4 - the site where the bracelet was found; 5 - Kostrová jaskyňa cave; 7 - burial ground (Early to Late Bronze Age); 8 - Kamenná tvár cave; 9 - Slaninová jaskyňa cave. 

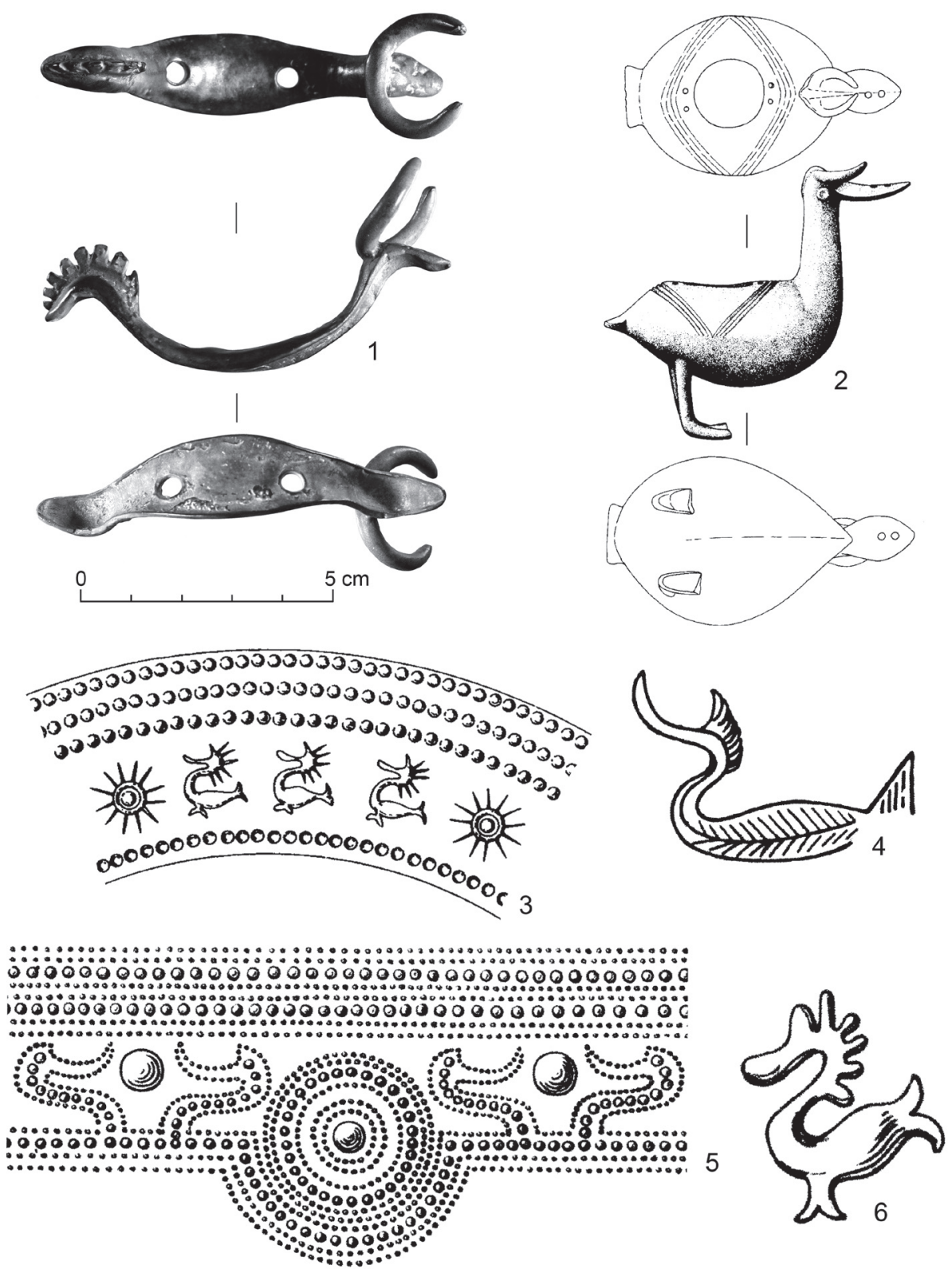

Obr. 2. 1 - Bôrka, poloha Havrania skala (Foto A. Marková); 2 - Čičarovce (podl'a Novotná 1991); 3 - Hlásnica u Horákova (výsek podl'a Podborský a kol. 1993); 4 - Falerii (podl'a Kossack 1954); 5 - výzdoba vedra typu Hajdúböszörmény (výsek podl'a Patay 1990); 6 - Hallstatt (podl'a Kossack 1954); 2-6 rôzna mierka.

Fig. 2. 1 - Bôrka, Havrania skala site (Foto A. Marková); 2 - Čičarovce (according to Novotná 1991); 3 - Hlásnica u Horákova (segment according to Poborský a kol. 1993); 4 - Falerii (according to Kossack 1954); 5 - decoration of the Hajdúböszörmény bucket (segment according to Pattay 1990); 6 - Hallstatt (according to Kossack 1954); 2-6 different scales. 
V mladšej a neskorej dobe halštatskej sa v štylizovanej podobe objavujú na ohybe ucha šálok v západnej časti Karpatskej kotliny. Ojedinelé nálezy sú z juhovýchodného Slovenska. Presnejšie časové ohraničenie ich výskytu na výšinných sídliskách $\mathrm{v}$ regióne Spiša je problematické (Miroššayová 1994, 48, tam d’alšia literatúra). Symbolika býka vo forme rohatých výčnelkov pretrváva do včasnolaténskeho stupňa LT A (napríklad šálky z pohrebiska v Stupave - $B a$ zovský - Čambal 2012, 162 obr. 235).

\section{Nález z Bôrky v kontexte s osídlením mikroregiónu Zádielska tiesňava}

V mladšej až neskorej dobe bronzovej bolo územie Slovenského krasu intenzívne osídlené nositel'mi kyjatickej kultúry a ich potomkovia prežívajú do začiatku doby halštatskej (stupeň HC). Príchod východných jazdeckých skupín do Potisia a ich prítomnost' na susednom území severného Mad’arska prispela k postupným zmenám kultúrneho vývoja a materiálnej kultúry obyvatelov Slovenského krasu. Od stupňa HD je jeho územie severnou okrajovou zónou severovýchodnej skupiny vekerzugskej kultúry.

Malé hradisko na polohe Havrania skala (770 m n. m.) v katastri obce Bôrka, okr. Rožňava s rozlohou približne 7 ha chránia strmé skalné steny a valové opevnenie kamenno-hlinitej konštrukcie (Furmánek 1984, 30; Miroššayová 2004, 354). Poloha hradiska posunutého hlboko do krasového územia vybudovaného na konci Zádielskej tiesňavy bola strategicky výhodná (obr. 1: 1). Obyvatelom poskytovala dostatočnú ochranu a súčasne umožňovala kontrolu nad prechodom do Rožňavskej kotliny cez Baksovu dolinu. Povrchovou prospekciou boli z areálu hradiska získané zlomky keramiky kyjatickej kultúry a železná troska. Z polohy Havrania skala sa uvádza nestratifikovaný a presnejšie nelokalizovaný nález bronzového hrotu šípu s troma krídelkami a tulajkou (Soják 2007, 70, obr. 101: 2).

Hradisko na Havranej skale patrilo do sídliskovej enklávy, ktorá sa v neskorej dobe bronzovej a na začiatku doby halštatskej sformovala v blízkosti Zádielskej tiesňavy a susednej Hájskej doliny. Okrem hradiska Havrania skala patrilo do enklávy vel'ké hradisko na Zádielskej planine (600 m n. m.) s plochou 110 ha nad vstupom do Zádielskej tiesňavy (obr. 1: 2). Na juhu ho prirodzene chránili strmé skalné steny, na severe mohutný val, priečne pretínajúci planinu. Zvyšky valu sú v súčasnosti miestami zachované do výšky $3 \mathrm{~m}$. Z areálu hradiska sú nálezy keramiky z neolitu, doby bronzovej a doby laténskej ( ka 1981, 290). Hospodárskym zázemím hradísk boli otvorené osady na južnom predpolí Zádielskej tiesňavy a Hájskej doliny (obr. 1: 3, 6). Špecifické postavenie v sídliskovej štruktúre mala Kostrová jaskyňa v južnej skalnej stene Zádielskeho hradiska (obr. 1: 5) s početnými nálezmi ludských kostí (Bárta 1975) a jaskyne Slaninová a Kamenná tvár v katastri obce Háj (Kaminská 1993, 13; Miroššayová 2007).

\section{Nálezy cudzej proveniencie}

V okolí Zádielskej tiesňavy sa koncentrujú ojedinelé nálezy cudzej proveniencie. $\mathrm{K}$ tunajším obyvatelom sa pravdepodobne dostali ako hotové výrobky obchodom, ako dar alebo koristé. Predstavujú špecifickú skupinu luxusných predmetov. Ani jeden z nálezov však nebol odborne vyzdvihnutý, čo komplikuje ich presnejšiu klasifikáciu. Miesto nálezu bronzového náramku s pečatítkovitými koncami (obr. 1: 4; 3: 5) nájdeného na povrchu oráčiny je lokalizované západne od obce Zádiel (Miroššayová 1992, 74n.). Forma a výzdoba náramku je porovnatelná s náramkami z juhovýchodného a severozápadného Balkánu datovanými do obdobia rokov 650-550 pred 

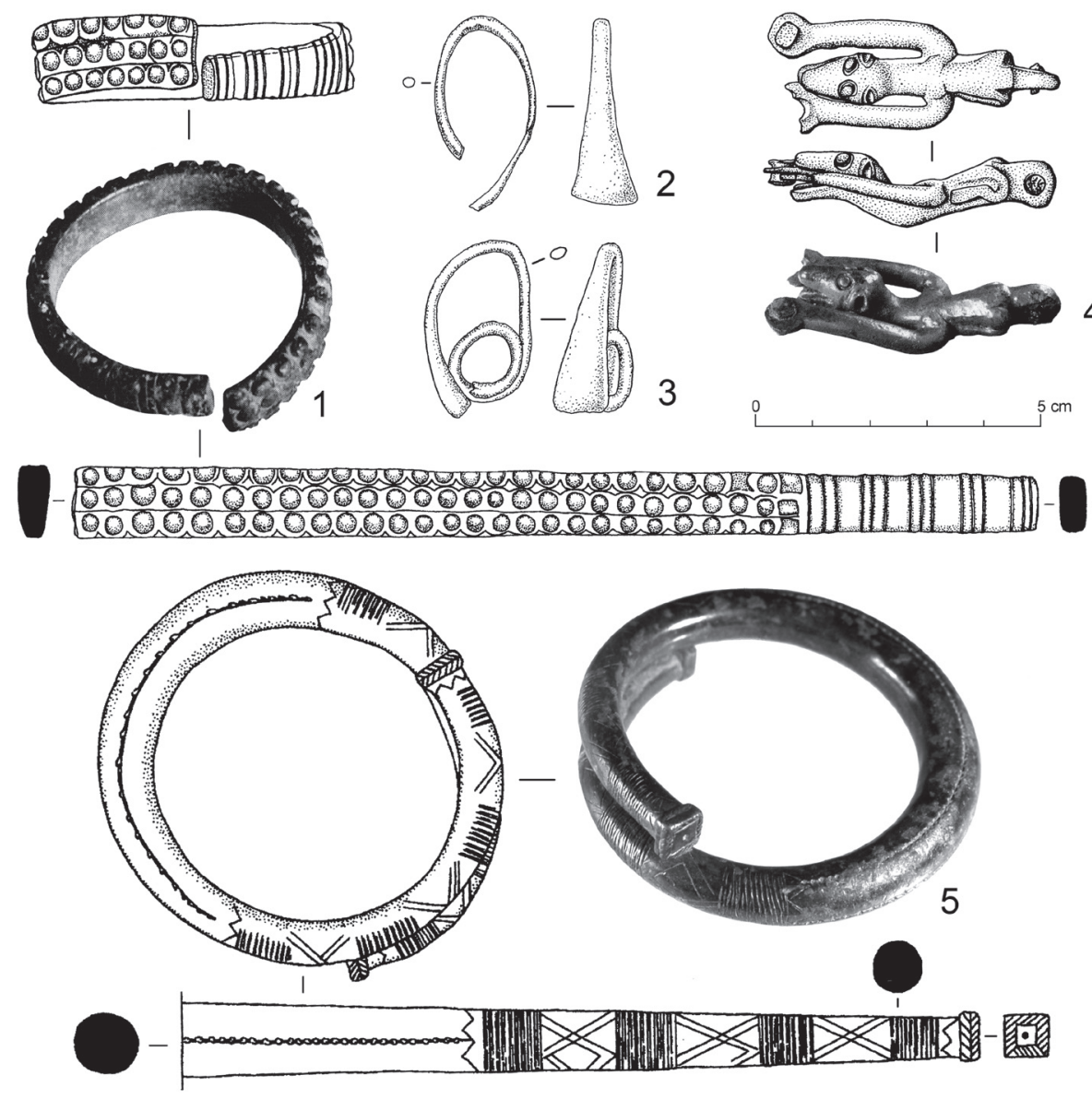

Obr. 3. 1, 4 - Háj, jaskyňa Kamenná tvár; 2, 3, 5 - Zádiel. (Foto A. Marková; Kresby: autorka; A. Bajalynov).

Fig. 3. 1, 4 - Háj-Kamenná tvár cave; 2, 3, 5 - Zádiel.

Kr. (Vrtište, Hrtkovci, Grivac - Vasić 1977, 19, niektorých pukličkách sú viditelné stopy po 21, 33, Pl. 21: 17, 18; 22A: 3, 4; 23: 56). Územne razidle. Porovnatelné analógie k typu náramku a časovo najbližšou analógiou k zádielskemu ná- v blízkom a vzdialenejšom okolí zatial chýbajú. lezu je nestratifikovaný nález zlomku náramku V Potisí sa mu usporiadaním pukličiek pribliz pohrebiska Alsótelekes-Dolinka v severnom žuje výzdoba na tele ryby zo zlatého plechu Mad’arsku (Kemenczei 2009, Taf. 136: 21). z Békéscsaby (nález z roku 1891 - Kemenczei

Z jaskyne Kmenná tvár v Háji pochádza časṫ 2009, 117, Taf. 9: 8). Uvádzané nálezy sú si časoliateho bronzového náramku (obr. 1: 8; 3: 1) vo blízke. Čast̉ náramku sa našla v špeciálnom z masívnej tyčinky zdobenej troma radmi puk- nálezovom kontexte. Jaskyňa Kamenná tvár ličiek a zväzkami rýh na hladkom konci. Na s priepastovým vstupom a vnútorným priesto- 
rom nevhodným na trvalejší pobyt bola v dobe halštatskej miestom rituálnych praktík spoločenstva žijúceho v jej okolí (Miroššayová 2007). Okrem bežných úžitkových predmetov sa v jaskyni našli aj vzácne predmety z bronzu, drahých kovov a sklenené koráliky $\mathrm{z}$ rozpätia stupňov HC-HD. Zámerné poškodenie rozseknutím náramkov a odseknutím hrotu ihlice a následné uloženie ich častí v jaskyni, signalizuje spôsob obety na princípe pars pro toto. Z jaskyne pochádza unikátna plastika psíka, ktorá pôvodne bola pripevnená na bronzovej nádobe ako pohyblivé ramienko, pravdepodobne pridržiavajúce pokrievku alebo sitko (obr. 3: 4). Podporou pre takúto interpretáciu je sitko z kniežacieho hrobu v Novom Pazare v centrálnej časti Balkánu, na ktorom má ramienko tvar koníka (podrobnejšie - Miroššayová 2007, 42).

$\mathrm{V}$ balkánskom prostredí môžeme pravdepodobne hl'adat' vzdialené predlohy pre jeden celý a jeden neúplný bronzový závesok zo Zádielu $^{2} \mathrm{z}$ drôtu kruhového prierezu na jednom konci trapézovite rozšírenom (obr. 3: 2, 3). Pre závesky, ktoré tvorili pár, priame analógie nie sú známe. Koncepcia tvaru záveskov zo Zádielu je príbuzná striebornému drôtenému náramku s trapézovite rozšíreným koncom z Vrtište v juhovýchodnom Srbsku (Vasić 1977, Pl. 21: 13) alebo striebornému prsteňu $\mathrm{z}$ mohylového hrobu zo 6.-5. stor. pred Kr. v Pećka Banja na území Kosova (Krstić 2004, 39, 94, obr.55). Závesky zo Zádielu môžu byt’ miestne, lacnejšie napodobeniny vzdialených honosných predlôh. Podla odlomeného konca stočeného drôtu na celom závesku (obr. 3: 3) sa zdá, že jeho terajšia podoba je sekundárna po úprave väčšieho predmetu (náramku?).

Typy náramkov, bronzová plastika a závesky s pôvodom alebo predlohami v kultúrnom prostredí centrálneho a severozápadného Balkánu sa na územie Slovenského krasu dostali po trase vedúcej pozdíž pravého brehu Tisy, vyznačenej nálezmi bronzových predmetov balkánskej pro- veniencie (Kemenczei 1988, 108n., Abb. 1). Problematikou kontaktov medzi spoločenstvami Karpatskej kotliny a severozápadného Balkánu v závere doby bronzovej a v staršej dobe halštatskej sa podrobnejšie zaoberala E. Studeníková v spojitosti s basarabskými nálezmi na juhozápadnom Slovensku. Upozornila, že okrem potiskej a podunajskej trasy viedla d’alšia spojnica s balkánskym prostredím cez povodie Drávy k juhovýchodohalštatským skupinám a cez nich trasa pokračovala d’alej na sever (Studeniková 2005, 75).

\section{Záver}

Nález z Bôrky rozširuje skupinu ojedinelých typov kovových predmetov, ktoré sa v staršej dobe halštatskej dostali na územie Slovenského krasu z juhu cez Potisie alebo zo Zadunajska. Pôvod bronzového predmetu z Bôrky sa s istotou nedá určit. S prihliadnutím na použité zoomorfné symboly a štýl vtáčej hlavy s chocholom, ku ktorým sú predlohy vo východohalštatskom kultúrnom prostredí, prikláňam sa k možnosti spojenia predmetu s uvedeným prostredím. V dobe halštatskej udržiavali obyvatelia Košickej kotliny kontakty s populáciami východohalštatských kultúr. Ich stopy dobre dokumentuje keramický inventár. V mladšej dobe halštatskej sa keramika s predlohami v západokarpatskom prostredí vyskytuje spoločne s formami v ruke a na kruhu robenej keramiky vekerzugskej kultúry. Bronzovému predmetu z Bôrky sú najbližšie nestratifikované nálezy zlomkov malovanej keramiky a uška s rohatými výčnelkami zo Zádielu, osady situovanej na južnom predpolí Zádielskej tiesňavy. V širšom okolí sú podobné nálezy z Vel'kej jasovskej jaskyne v Jasove a z Čečejoviec (Miroššayová 2013, obr. 2: 2-7; 3: 2-5). Zo sídliskových objektov v Čečejovciach je sortiment západokarpatských prvkov širší. Patrí k nim tuhovaná výzdoba, vertikálne vypukliny 
na vydutí váz, štylizované zvieracie hlavičky na ohybe ucha šálok a výrazne profilované misky (1. c., 181, obr. 3: 1, 4, 6-11). Bronzový predmet z Bôky sa k obyvatelom Slovenského krasu mohol dostat priamo alebo sprostredkovane ako hotový výrobok spolu s d’alšími artefaktmi zá- padokarpatského charakteru, ale nevylučujem, že bol vyrobený miestnym kovolejárom inšpirovaným východohalštatskými predlohami použitých symbolov.

Za grafickú úpravu obrázkov d’akujem Bc. A. Markovej.

1) Názov uvádzaný na nových mapách. V literatúre sa vyskytuje pomenovanie Vranie skaly (napr. Soják 2007, Obr. 102).

2) Bližšia lokalizácia nálezu nie je známa.

\section{Literatúra}

Bárta, J. 1975: Speleoarcheologický výskum Kostrovej jaskyne pri Zádielskych Dvorníkoch. Archeologické výskumy a nálezy na Slovensku v roku 1974. Nitra, 17-19.

Bazovský, I. - Čambal, R. 2012: Od keltských osád k oppidu. In: Šedivý, J. - Štefanovičová, T. (zost.): Dejiny Bratislavy 1. Od počiatkov do prelomu 12. a 13. storočia. Brezalauspurc na križovatke kultúr. Bratislava, 162-163.

Furmánek V. 1984: Hradiská pilinskej a kyjatickej kultúry na Slovensku. Archeologické Rozhledy XXXV, 24-32.

Kaminská, L. 1993: Príspevok k osídleniu jaskýň v Slovenskom krase. Východoslovenský pravek 4, 13-25.

Kemenczei, T. 1988: Zu den Beziehungen zwischen dem ungarischen Donau-Theissraum und dem NW-Balkan in der Früheisenzeit. Folia Archaeologica XXXIX, 93-113.

Kemenczei, T. 2009: Studien zu den Denkmälern scythisch Geprägter Alföld Gruppe. Budapest.

Kmetová, P. 2014: Deponovanie koní na pohrebiskách z doby halštatskej v priestore Panónskej panvy. Dissertationes Archaeologicae Bratislavenses 2, Bratislava.

Kmetová, P. - Stegmann-Rajtar, S. 2015: Symbolické uloženie lebky koňa v hroboch v závere doby popolnicových polí a v počiatkoch doby halštatskej. In: Oždány, O. (ed.): Popolnicové polia a doba halštatská. Nitra, 73-92.
Kossack, G. 1954: Studien zum Symbolgut der Urnenfelder- und Hallstattzeit Mitteleuropa. Röm.-Germ. Forschungen 20. Berlin.

Krieger und Salzherren. 1970: Hallstattkultur im Ostalpenraum. Austellungskatalog. Mainz.

Krstić, V. 2004: Die Fürstengräber der Älteren Eisenzeit im Zentralbalkan. In: Silber der Illyrer und Kelten im Zentralbalkan. Ausstellungskatalog. Schriftenreihe des Keltenmuseums Hochdorf/ Enz 6, 33-50.

Miroššayová, E. 1984: Výskum a prieskum mikroregiónu Zádielska dolina. Archeologické výskumy a prieskumy na Slovensku v roku 1983, 153, 154.

Miroššayová, E. 1992: Bronzové náramky zo Zádielskych Dvorník. Archeologické výskumy a nálezy v roku 1990. Nitra, 74, 75.

Miroššayová, E. 1994: Sídlisko z neskorej doby halštatskej v Čečejovciach. Slovenská archeológia XLII, 37-68.

Miroššayová, E. 2004: Nálezy z doby halštatskej vo východnej časti Slovenského krasu. Popelnicová pole a doba halštatská. Archeologické výzkumy v jižních Čechách. Suplementum 1, České Budějovice, 351-364.

Miroššayová, E. 2007: Príspevok k nálezom z doby halštatskej v jaskyniach Slovenského krasu. Východoslovenský pravek VIII, 33-57.

Miroššayová, E. 2013: Príspevok k problematike kontaktov medzi západokarpatským a severopotiským 
prostredím v dobe halštatskej na podklade keramiky z Košickej kotliny. Zborník Slovenského národného múzea 107, Archeológia 23, 175-183.

Novotná, M. 1991: Die Bronzegefässe in der Slowakei. Prähistorische Bronzefunde. Abteilung II, Band 11. Stuttgart.

Patay, P. 1990: Die Bronzegefässe in Ungarn. Prähistorische Bronzefunde. Abteilung II, Band 10. München.

Pichlerová, M. 1969: Nové Košariská. Kniežacie mohyly zo staršej doby železnej. Bratislava.

Podborský, V. a kol. 1993: Vlastivěda moravská. Země a lid. Nová řada. Sv. 3 , Brno.

Studeniková, E. 2005: Kalenderbergská kultúra na juhozápadnom Slovensku a juhovýchodná Európa.
In: Studeníková, E. (ed.): Južné vplyvy a ich odraz v kultúrnom vývoji mladšieho praveku na strednom Dunaji. Zborník referátov z konferencie z 9. novembra 2004 v Bratislave. Bratislava, 73-88.

Soják, M. 2007: Osídlenie blízkeho okolia Moldavy nad Bodvou. In: Soják, M. - Terray, M. (zost.): Moldavská jaskyňa $\mathrm{v}$ zrkadle dejín. Moldava nad Bodvou, 50-72.

Šiška, S. 1981: Nové nálezy z povodia Bodvy. Archeologické výskumy a nálezy na Slovensku v roku 1980. 289-291.

Vasić, R. 1977: The chronology of the Early Iron Age in the Socialist Republik of Serbia. BAR Supplementary Series 31, Oxford.

\section{The bronze object with zoomorphic protomes from the Slovak Karst}

According to the available data, the object was found at the site of Havrania skala, in the residential area of the village of Bôrka, Rožňava district, in the northern part of the Slovak Karst (Fig. 1: 1). Further information on the find context is absent (Soják 2007, obr. 102). The shape of the object is inspired by the form of the so-calle "sun boat" (Fig. 2: 1). Application of various cultic symbols - a bull's head and a bird - is very unusual. More precise functional and chronological classification of the object is limited by the absence of information on the find context. A small hillfort at Havrania skala, with the area of approx. 7 ha, was protected by steep rock walls and a rampart fortification with stone-earth construction (Furmánek 1984, 30; Miroššayová 2004, 354). The hillfort belonged to the settlement agglomeration connected with the Zádielska tiesňava canyon and the nearby Hájska dolina valley (Fig. 1). Another hillfort at Zádielska planina plain with the area of 110 ha (Fig. 1: 2) was part of the agglomeration as well as were the settlements on the southern foreground of the Zádielska tiesňava canyon and Hájska dolina valley in the territory of Zádiel and Háj (Fig. 1: 3, 6). The Kostrová, Slaninová and Kamenná tvár caves
(Fig. 1: 5, 8,9) had a specific status in the settlement structure (Miroššayová 2007). In the younger and late Bronze Age, the territory was intensely settled by the Kyjatice culture people who survived until the beginning of the Hallstatt period. The arrival of groups of eastern riders to the Tisza region and their presence on the neighbouring territory of northern Hungary contributed to gradual changes in the cultural development on the territory of the Slovak Karst. In the find inventory from the Hallstatt period discovered near the Zádielska tiesňava canyon, we have documented a specific group of individual foreign finds which originated in the environment of the northwestern Balkans (Fig. 3). One route along which the Balkan finds spread northwards led through the area on the right bank of the Tisza river (Kemenczei 1988, 108n., Abb. 1), another one crossed the Drava river valley and the Danubian river route to Transdanubia (Studeníková 2005, 77). The origin of the bronze object from Bôrka cannot be determined definitely. Besides the northwestern Balkans, we can take the east Hallstatt cultural environment into consideration. Traces of the east Hallstatt influence near the Zádielska tiesňava canyon are documented by fragments of painted pottery. 


\section{PhDr. Elena Miroššayová, CSc.}

- Archeologický ústav SAV

Oddelenie pre výskum východného Slovenska

Hrnčiarska 13, SK - 04001 Košice

mirossa@saske.sk 